\title{
Concrete beam subjected to shear and torsion: a comparison between the Brazilian Standard Code NBR 6118, ACI and AASHTO Provisions
}

\section{Viga de concreto armado sujeita ao cisalhamento e torção: uma comparação entre a Norma Brasileira ABNT NBR 6118: 2014, ACI 318/2014 e a AASHTO}

R. C. DE ANDRADE a

rebecca.andrade@usp.br https://orcid.org/0000-0002-6329-6916

T. N. BITTENCOURT a

tbitten@usp.br https://orcid.org/0000-0001-6523-2687

\begin{abstract}
Most of torsion studies available are relative to pure torsion, arising from the exclusive application of a torsion moment in a concrete beam. This situation, however, is only possible in laboratories. In practice, the vast majority of twisted beams are subjected to the combination of shear forces and torsion, which gives rise to a more complex state of stress to be analyzed. The purpose of this paper is to present the provisions of the ACl $318 / 2014$ Codes, AASHTO and ABNT NBR 6118: 2014 related to shear and torsion, and compare some results with experimental data from Rahal \& Collins[3] It is shown that if the recommended value of $45^{\circ}$ is used for $\theta$, the $\mathrm{ACl} 318 / 2014$ provisions for shear-torsion interaction give similar results compared to ABNT NBR6118: 2014, but these results are very conservative. If the lower limit of $30^{\circ}$ is used, the results obtained using both codes departs, and less consistent results are obtained. This paper concludes that using the recommended value of $36^{\circ}$ obtained with the AASHTO provisions, some consistent and more accurate results are obtained.
\end{abstract}

Keywords: torsion, shear, concrete beams, ACI 318/2014 provisions, ABNT NBR 6118: 2014 provisions.

\section{Resumo}

A maioria dos estudos sobre torção feitos até hoje contempla a torção pura, decorrente da aplicação exclusiva de um momento torsor em uma viga de concreto armado. Esta situação, no entanto, só é possível em laboratórios. Na prática, a grande maioria das vigas é submetida à combinação de forças de cisalhamento e torção, o que gera um estado de tensão mais complexo a ser analisado. O objetivo deste artigo é apresentar os modelos de cálculo das normas ACI 318/2014, AASHTO e ABNT NBR 6118: 2014 relacionadas ao cisalhamento e torção, e comparar alguns resultados com dados experimentais de Rahal \& Collins [3]. É mostrado que, se o valor recomendado de $45^{\circ}$ é usado para $\theta$, os procedimentos normativos da ACl 318/2014 para a interação cisalhamento-torção fornecem resultados semelhantes comparados aos obtidos pela ABNT NBR 6118: 2014, porém esses resultados podem ser considerados muito conservadores. Se o limite inferior de $30^{\circ}$ for utilizado, os resultados obtidos usando os dois códigos se divergem e resultados menos consistentes serão obtidos. Este artigo conclui que, usando o valor recomendado de $36^{\circ}$ para $\theta$, de acordo com as recomendações da AASHTO, resultados mais consistentes são obtidos.

Palavras-chave: torção, cisalhamento, vigas de concreto armado, ACI 318/2014, ABNT NBR 6118: 2014.

Polytechnic School of Engineering of University of São Paulo, São Paulo, SP, Brazil. 


\section{Introduction}

Since the beginning of Century XX, torsion has been studied based on the fundamental concepts of Material Engineering and the Theory of Elasticity. The first researchers that were recognized by their studies in finding out a solution for the torsion problem in structures were Saint-Venant and Prandtl. After that, another scientist that must be highlighted because of his great contribution to applied mechanics was Bredt, who offered a promising solution to the Saint-Venant torsion problem, using thin-wall hollow section tubes.

One of the first engineers to propose the application of the concept of truss model to shear was Mörsch. He considered the beam behavior analogous to an isostatic truss, in which the upper and lower chords are parallel, and represented respectively by the region of the compression concrete and the longitudinal tensile reinforcement bars of the beam. There are compression concrete struts inclined at $45^{\circ}$ degrees to the longitudinal axis of the beam between the chords, and a tie inclined at an angle $\alpha$ which can vary from $45^{\circ}$ to $90^{\circ}$, located transversely to the concrete cracks, as shown in Fig.1.
The loads in the compression strut and tie increase in intensity from the center of the beam towards the support conditions, where the shear force presents its maximum value. By contrast, the forces on the compression chord and longitudinal tensile reinforcement bars reach their peak in regions near the middle of the span.

Later, Leonhardt \& Mönnig found out in their research that the measured stresses in the transverse reinforcement were lower than those expected in the design, implying that the theoretical model of classical truss led to high values of transverse reinforcement. The observations made by Leonhardt \& Mönnig are due to several factors. The first is that the compression chord is relatively inclined when compared to the tensile chord, allowing the concrete to absorb part of the shear force. Due to this inclination, the $R_{s t}$ load acting on the longitudinal reinforcement is greater than the $R_{c c}$ load acting on the compression chord. Regarding the diagonals, the cracks and the struts between them are variably inclined in relation to the longitudinal axis of the beam presenting inclinations lower than $45^{\circ}$.

The relative stress decrease in the transverse reinforcement is due to alternative forms of shear force absorption developed with the

\section{(a) Crack Pattern}

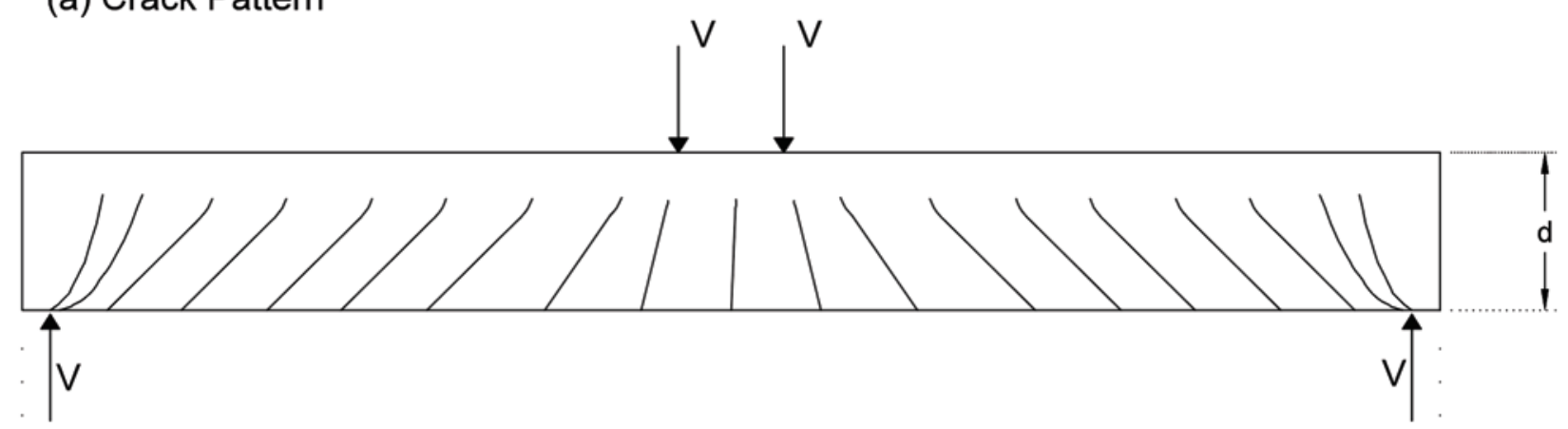

(b) Strut-and-ties Model

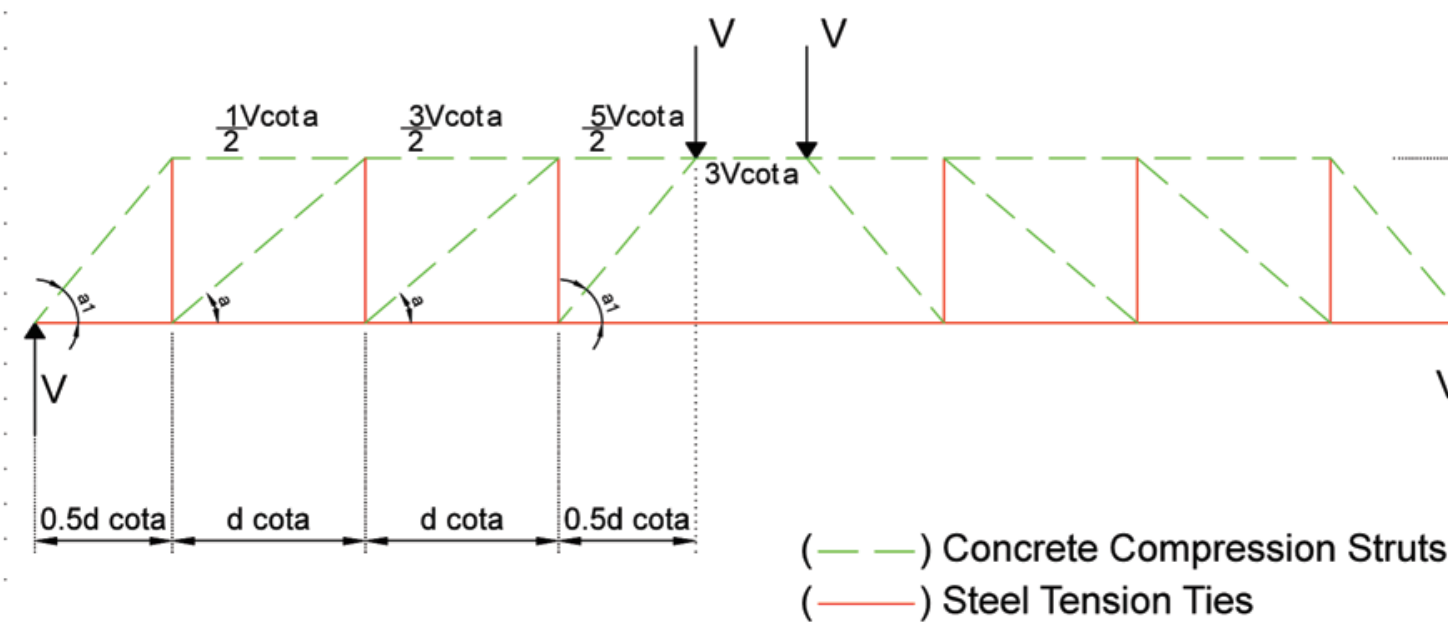

Figure 1

Struts-and-ties model of a concrete beam with bottom longitudinal rebars and stirrups resisting shear and bending 
truss. These forms are the Arc effect, the interlocking aggregate effect and the dowel effect of the longitudinal reinforcement bars.

Based on the results presented by Leonhardt \& Mönnig and on the design of the space truss, the Brazilian Standard Code ABNT NBR 6118:2014 indicates a calculation model for reinforced concrete beam elements subjected to torsion. It is assumed that the transverse reinforcement has inclinations ranging from $45^{\circ}$ to $90^{\circ}$, and that the design torsion must be less than or equal to the resistance capacity of the compression strut.

Historically, shear design in the United States has included a concrete contribution, $V_{c}$, to supplement the $45^{\circ}$ sectional truss model to reflect test results in beams and slabs with little or no reinforcement and to ensure economy in the practical design of such members. ACI Standard Specification No. 23 (1920) permitted an allowable shear stress of $0.025 f_{c}$ ' but not more than $0.41 \mathrm{MPa}$, for beams without web reinforcement, and with longitudinal reinforcement that did not have "mechanical anchorage" (see Fig.2).

The August 1955 shear failure of beams in the warehouse at Wilkins Air Force Depot in Shelby, Ohio, brought into question the traditional $\mathbf{A C l}$ shear design procedures. These shear failures, in conjunction with intensified research, clearly indicated that shear and diagonal tension was a complex problem involving many variables and resulted in a return to forgotten fundamentals.

Collins \& Mitchell [10] (1980) abandoned the assumption of linear elasticity and developed the compression field theory (CFT) for members subjected to torsion and shear. Based on extensive experimental investigation, Vecchio \& Collins [9] (1982, 1986) presented the modified compression field theory (MCFT), which included a rationale for determining the tensile stresses in the diagonally cracked concrete. Although the CFT works well with medium to high percentages of transverse reinforcement, the MCFT provides a more realistic assessment for members having a wide range of amounts of transverse reinforcement including the case of no web reinforcement.

Torsion design provisions were first considered in the ACI Building Code in 1971. They assumed by then that both the torsional strength and the shear strength could be expressed as the sum of the contributions of the concrete $\left(T_{c}\right.$ or $V_{c}$ ) and the steel ( $T_{s}$ or $V_{s}$ ). The steel contribution was about the capacity predicted by a truss model with compression diagonals inclined at $45^{\circ}$, while the concrete contributions were related to the diagonal cracking loads. A circular interaction curve was assumed in determining $T_{c}$ and $V_{c}$ under combined shear and torsion.

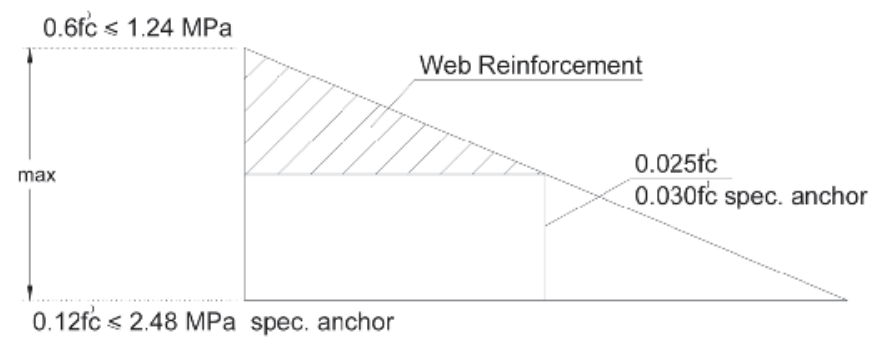

Figure 2

American specification for shear design (1920-1951) based on ACl Standard No.23, 1920
In 1995, the ACl Code simplified the torsion design provisions by eliminating $T_{c}$ and by neglecting the influence of torsion on $V_{c}$. Also, the torsional strength was now expressed in terms of a space truss model with compression diagonals inclined at an angle $\theta$ to the longitudinal axis of the member. For nonprestressed members a value of $45^{\circ}$ was recommended for $\theta$; however, values as low as $30^{\circ}$ were permitted.

The AASHTO-LRFD Bridge Design Specifications contain torsion design provisions that are similar in many respects to those in the current $\mathrm{ACl}$ Code. The significant difference is that the angle $\theta$ is determined based on the longitudinal strain conditions of the section in the AASHTO provisions and the procedures used are based on the modified compression field theory.

In this study, the inclination of the concrete compression strut is the main variable that is evaluated in order to compare the standards. How the variation of the angle $\theta$ influences the results of the concrete contribution to resist shear and how the failure of the concrete strut is verified by the codes are shown.

\section{Brazilian Standard Code ABNT NBR 6118: 2014 Provisions for Shear and Torsion}

For reinforced concrete beam elements subjected to shear force, the Brazilian Standard Code proposes two different calculation models which are widely discussed. The Brazilian Standard Code ABNT NBR 6118:2014 sets conditions for the verification of reinforced concrete beam elements subjected to shear force, possibly combined with other action effects, allowing two calculation models. Such models are based on the parallel chord truss analogy, initially studied by Mörsch, in which the angle $\theta$ of inclination of the strut can be considered constant and equal to $45^{\circ}$ (model I) as shown in equation [1], or ranging from $30^{\circ}$ to $45^{\circ}$ (model II) as shown in equation [2]. Equation [1a] verifies the compression in the concrete strut and equation [1b] calculates the stirrups. Equation [2a] calculates the design shear resistance in relation to the capacity of the compression of the concrete strut, and equation [2b] obtains the transverse reinforcement. Equation [2c] is derived by Barros \& Giongo [4] by linear interpolation, and the value of $V_{c 1}$ equals $V_{c 0}$ when the value of $V_{s d}$ equals $V_{c 0}$. Similarly, $V_{c 1}$ equals zero when the design value of shear force $V_{S d}$ equals the value of the design shear resistance $\mathrm{V}_{\mathrm{Rd} 2}$.

The stirrups may present inclination a between $45^{\circ}$ and $90^{\circ}$, but it is usually used with an inclination of $90^{\circ}$.

$V_{s d} \leq V_{R d 2}=0.27\left(1-\frac{f_{c k}}{250}\right) f_{c d} b_{w} d$

$V_{s d} \leq V_{R d 3}=V_{c}+V_{s w}$

$V_{s w}=\left(\frac{A_{s w}}{s}\right) 0.9 d f_{y w d}(\sin \alpha+\cos \alpha)$

$V_{c 0}=0.6 f_{c t d} b_{w} d$

$f_{c t d}=0.15 \sqrt[3]{f_{c k}^{2}}$

$V_{s d} \leq V_{R d 2}=0.54\left(1-\frac{f_{c k}}{250}\right) f_{c d} b_{w} d(\sin \theta)^{2}(\cot \alpha+\cot \theta)$

$V_{s d} \leq V_{R d 3}=V_{c}+V_{s w}$

$V_{s w}=\left(\frac{A_{s w}}{s}\right) 0.9 d f_{y w d} \sin \alpha(\cot \alpha+\cot \theta)$ 
$V_{c 1}=\left(\frac{V_{R d 2}-V_{S d}}{V_{R d 2}-V_{c 0}}\right) V_{c 0}$

As it has been concluded and shown by Barros \& Giongo [4] that model I leads to high values of the transverse reinforcement area compared to model II, when using the strut angle inclined between $30^{\circ}$ and $39^{\circ}$. These results are justified by the fact that model I is a simplification of model II, therefore, it tends to be more conservative when considering solely the values of the transverse reinforcement, and not the offset of tensile chord loads diagram effect.

ABNT NBR 6118:2014 fixes conditions for the verification of reinforced concrete beam elements subjected to torsion combined with other structural loads, assuming a resistant model (space truss) which is defined based on a structural element with hollow section equivalent to the structural element to be designed. That allows the angle $\theta$ of the strut inclination to have its value ranging between $30^{\circ}$ and $45^{\circ}$. ABNT NBR 6118: 2014 requires the angles of the strut inclination to be the same as determining resistance when there is a combination of torsion and shear force.

Fig. 3 shows the resultant forces in the reinforcement bars in a structural part submitted exclusively to torsion. The $\mathrm{R}_{\mathrm{sl}}$ force represents the results of tensile stresses in the longitudinal reinforcement bars distributed along the element section. The $R_{s 90}$ force is the resultant of tensile stresses on stirrups positioned at $90^{\circ}$, in relation to the part axis. The $R_{c w \text { tor }}$ forces represent the resultant of the compression loads in the compressed struts.

It is assumed that the transverse reinforcement can have inclinations ranging from $45^{\circ}$ to $90^{\circ}$, and that the design torsion must be

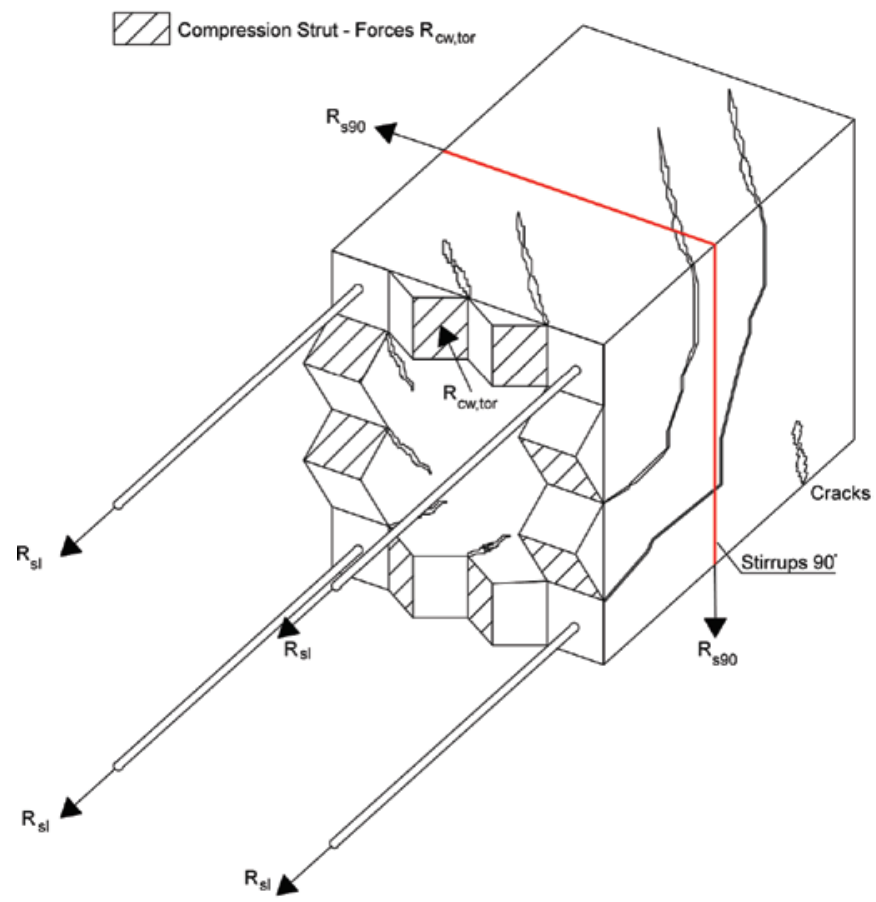

Figure 3

Model of section filled with simple torsion adapted from Leonhardt \& Mönnig [4] less than or equal to the resistance capacity of the compression strut $\left(T_{\mathrm{Rd} 2}\right)$, which is given by expression [3].

$T_{s d} \leq T_{R d 2}=0.50\left(1-\frac{f_{c k}}{250}\right) f_{c d} A_{e} h_{e} \sin (2 \theta)$

where $A_{e}$ is the area enclosed by the centerline of the wall of the hollow section, $h_{e}$ is the thickness of the equivalent wall, $f_{c k}$ is the concrete characteristic resistance to compression and $f_{c d}$ is the value for calculating the concrete resistance to the direct compression.

Besides the verification of the compression strut, it is also necessary to verify the transverse and longitudinal reinforcement resistance. When stirrups present angle equal to $90^{\circ}$, the resistance condition is guaranteed by equation [4]. In this equation, the value of $A_{90}$ represents the cross-sectional area of the number of branches of a stirrup, which must be in the region of the equivalent wall. For the longitudinal reinforcement, equation [5] must be used.

$T_{s d}=T_{R d 3}=\left(\frac{A_{90}}{s}\right) f_{y w d} 2 A_{e} \cot (\theta)$

$T_{s d}=T_{R d 4}=\left(\frac{A_{s l}}{u_{e}}\right) f_{y w d} 2 A_{e} \tan (\theta)$

where the term $u_{e}$ is the perimeter of $A_{e}$.

\section{ACI and AASHTO-LRFD provisions for shear and torsion}

The basic truss equation relating the torsional strength to quantity of transverse reinforcement is as equation [6].

$T_{n}=2 A_{0}\left(\frac{A_{t} f_{y t}}{s}\right) \cot (\theta)$

where $A_{o}$ is the area enclosed by the shear flow path and $A_{t}$ is the area of one leg of closed transverse reinforcement. As shown in Fig. 4, $A_{o}$ is less than the area enclosed by the centerline of the outermost transverse torsional reinforcement $\left(A_{o n}\right)$. The $\mathrm{ACl}$ provisions permit $A_{o}$ to be taken as $0.85 A_{o h}$.

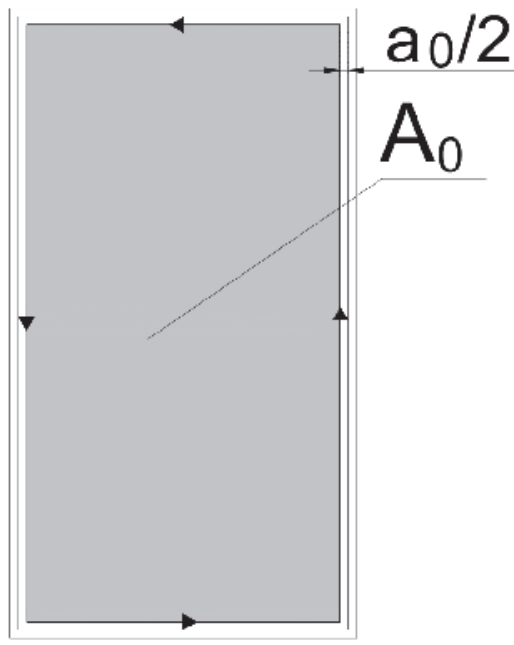

Figure 4

Area enclosed by shear flow for rectangular cross section 
Table 1

Values of $\theta$ and $\beta$ given by AASTO-LRFD

\begin{tabular}{|c|c|c|c|c|c|c|c|c|c|}
\hline \multirow{2}{*}{$\frac{v_{u}}{f_{c}^{\prime}}$} & \multicolumn{9}{|c|}{$\varepsilon_{\mathrm{x}} \times 1000$} \\
\hline & $\leq-0.20$ & $\leq-0.10$ & $\leq-0.05$ & $\leq 0$ & $\leq 0.125$ & $\leq 0.25$ & $\leq 0.50$ & $\leq 0.75$ & $\leq 1.00$ \\
\hline$\leq 0.075$ & $\begin{array}{l}22.3 \\
6.32\end{array}$ & $\begin{array}{l}20.4 \\
4.75\end{array}$ & $\begin{array}{l}21.0 \\
4.10\end{array}$ & $\begin{array}{l}21.8 \\
3.75\end{array}$ & $\begin{array}{l}24.3 \\
3.24\end{array}$ & $\begin{array}{l}26.6 \\
2.94\end{array}$ & $\begin{array}{l}30.5 \\
2.59\end{array}$ & $\begin{array}{l}33.7 \\
2.38\end{array}$ & $\begin{array}{l}36.4 \\
2.23\end{array}$ \\
\hline$\leq 0.100$ & $\begin{array}{l}18.1 \\
3.79\end{array}$ & $\begin{array}{l}20.4 \\
3.38\end{array}$ & $\begin{array}{l}21.4 \\
3.24\end{array}$ & $\begin{array}{l}22.5 \\
3.14\end{array}$ & $\begin{array}{l}24.9 \\
2.91\end{array}$ & $\begin{array}{l}27.1 \\
2.75\end{array}$ & $\begin{array}{l}30.8 \\
2.50\end{array}$ & $\begin{array}{l}34.0 \\
2.32\end{array}$ & $\begin{array}{l}36.7 \\
2.18\end{array}$ \\
\hline$\leq 0.125$ & $\begin{array}{l}19.9 \\
3.18\end{array}$ & $\begin{array}{l}21.9 \\
2.99\end{array}$ & $\begin{array}{l}22.8 \\
2.94\end{array}$ & $\begin{array}{l}23.7 \\
2.87\end{array}$ & $\begin{array}{l}25.9 \\
2.74\end{array}$ & $\begin{array}{l}27.9 \\
2.62\end{array}$ & $\begin{array}{l}31.4 \\
2.42\end{array}$ & $\begin{array}{l}34.4 \\
2.26\end{array}$ & $\begin{array}{l}37.0 \\
2.13\end{array}$ \\
\hline$\leq 0.150$ & $\begin{array}{l}21.6 \\
2.88\end{array}$ & $\begin{array}{l}23.3 \\
2.79\end{array}$ & $\begin{array}{l}24.2 \\
2.78\end{array}$ & $\begin{array}{l}25.0 \\
2.72\end{array}$ & $\begin{array}{l}26.9 \\
2.60\end{array}$ & $\begin{array}{l}28.8 \\
2.52\end{array}$ & $\begin{array}{l}32.1 \\
2.36\end{array}$ & $\begin{array}{l}34.9 \\
2.21\end{array}$ & $\begin{array}{l}37.3 \\
2.08\end{array}$ \\
\hline$\leq 0.175$ & $\begin{array}{l}23.2 \\
2.73\end{array}$ & $\begin{array}{l}24.7 \\
2.66\end{array}$ & $\begin{array}{l}25.5 \\
2.65\end{array}$ & $\begin{array}{l}26.2 \\
2.60\end{array}$ & $\begin{array}{l}28.0 \\
2.52\end{array}$ & $\begin{array}{l}29.7 \\
2.44\end{array}$ & $\begin{array}{l}32.7 \\
2.28\end{array}$ & $\begin{array}{l}35.2 \\
2.14\end{array}$ & $\begin{array}{l}36.8 \\
1.96\end{array}$ \\
\hline$\leq 0.200$ & $\begin{array}{l}24.7 \\
2.63\end{array}$ & $\begin{array}{l}26.1 \\
2.59\end{array}$ & $\begin{array}{l}26.7 \\
2.52\end{array}$ & $\begin{array}{l}27.4 \\
2.51\end{array}$ & $\begin{array}{l}29.0 \\
2.43\end{array}$ & $\begin{array}{l}30.6 \\
2.37\end{array}$ & $\begin{array}{l}32.8 \\
2.14\end{array}$ & $\begin{array}{l}34.5 \\
1.94\end{array}$ & $\begin{array}{l}36.1 \\
1.79\end{array}$ \\
\hline$\leq 0.225$ & $\begin{array}{l}26.1 \\
2.53\end{array}$ & $\begin{array}{l}27.3 \\
2.45\end{array}$ & $\begin{array}{l}27.9 \\
2.42\end{array}$ & $\begin{array}{l}28.5 \\
2.40\end{array}$ & $\begin{array}{l}30.0 \\
2.34\end{array}$ & $\begin{array}{l}30.8 \\
2.14\end{array}$ & $\begin{array}{l}32.3 \\
1.86\end{array}$ & $\begin{array}{l}34.0 \\
1.73\end{array}$ & $\begin{array}{l}35.7 \\
1.64\end{array}$ \\
\hline$\leq 0.250$ & $\begin{array}{l}27.5 \\
2.39\end{array}$ & $\begin{array}{l}28.6 \\
2.39\end{array}$ & $\begin{array}{l}29.1 \\
2.33\end{array}$ & $\begin{array}{l}29.7 \\
2.33\end{array}$ & $\begin{array}{l}30.6 \\
2.12\end{array}$ & $\begin{array}{l}31.3 \\
1.93\end{array}$ & $\begin{array}{l}32.8 \\
1.70\end{array}$ & $\begin{array}{l}34.3 \\
1.58\end{array}$ & $\begin{array}{l}35.8 \\
1.50\end{array}$ \\
\hline
\end{tabular}

Section 11.6.3.6 of the ACl Code states that the angle of inclination $\theta$ of the compression diagonals "shall not be taken smaller than 30 degrees." but then goes on to suggest that $\theta$ be taken equal to 45 degrees for nonprestressed members and 37.5 degrees for prestressed members. The commentary suggests that $\theta$ can be obtained by analysis.

The basic truss equation relating the torsional strength to the quantity of longitudinal reinforcement is [7].

$T_{n}=\frac{2 A_{0} A_{t} f_{y t}}{s} \cot (\theta)$

$T_{n}=2 A_{0}\left(\frac{A_{l} f_{y l}}{p_{h}}\right) \tan (\theta)$

The additional area of longitudinal reinforcement to resist torsion, $A_{1}$, shall not be less than [8]:

$A_{l}=\frac{A_{t}}{s} p_{h} \frac{f_{y t}}{f_{y l}}(\cot \theta)^{2}$

The amount of transverse reinforcement required to resist torsion $A_{t}$, must be added to the amount of transverse reinforcement required to resist shear $A_{v}$, while the amount of longitudinal reinforcement required to resist torsion must be added to the amount of longitudinal reinforcement required to resist flexure.

For a nonprestressed section, the $\mathrm{ACl}$ relationship between the shear strength and the amount of transverse reinforcement is [9]:

$V_{n}=V_{c}+V_{s}=0.166 \sqrt{f_{c}^{\prime}} b_{w} d+\frac{A_{v} f_{y}}{s} d$

where $b_{w}$ is the web width and $d$ is the distance from the extreme compressive fiber to the centroid of the flexural tension reinforcement. The factor 0.166 is for MPa units.

Equation [6] is also used in the AASHTO provisions. In AASHTO, the relationship between required shear strength $V_{n}$ and the amount of transverse reinforcement required to resist shear $\left(A_{v}\right)$ is as equation [9b].

$V_{n}=V_{c}+V_{s}=0.083 \beta \sqrt{f_{c}^{\prime}} b_{v} d_{v}+\frac{A_{v} f_{y}}{s} d_{v} \cot \theta$ where $b_{v}$ is the web width and $d_{v}$ is the effective shear depth, which can be taken as $0.9 \mathrm{~d}$. For sections with stirrups, the values of $\beta$ and $\theta$ depend on the nominal shear stress $v_{u}$ and the longitudinal strain at mid-depth of the section $\varepsilon_{\mathrm{x}}$, as shown in Table 1. Rahal \& Collins [1] pointed out that if $\beta$ equals 2.22 (that is, 2.0/0.9), then the AASHTO value of $\mathrm{V}_{\mathrm{c}}$ will be identical to the $\mathrm{ACI}$ value. For nonprestressed sections, $\varepsilon_{\mathrm{x}}$ can be taken as $1.00 \times 10^{-3}$ and so, $\theta$ from Table 1 will be approximately 36 degrees. With this value of $\theta$, the AASHTO expression will give a $24 \%$ higher value of $V_{s}$ than that given by the $\mathbf{A C l}$ expression ( $0.9 \cot 36$ equals 1.24$)$.

\section{Torsion and shear interaction}

Practically speaking, pure torsion only exists in laboratory. In actual structures, torsion is always combined with shear.

Some considerations must be made when the structural element is subjected to the combined effects of torsion and shear force. An important one is the adoption of equal inclination angles of the strut, which improves the safety analysis of the structural element related to torsion and shear force.

Under combined torsion and shear, both the ABNT NBR 6118: 2014 and the $\mathbf{A C l}$ consider the transverse reinforcement as the sum of that required to resist torsion and that required to resist shear. As shown in Rahal \& Collins [3], if $\mathrm{A}_{t}$ is the cross-sectional area of one leg of the transverse reinforcement and if two legs of transverse reinforcement are being used to resist shear, then the design requirement for the $\mathbf{A C l}$ can be expressed as equation [10a]:

$\frac{A_{t} f_{y}}{s}=\frac{V_{n}-V_{c}}{2 d}+\frac{T_{n}}{2 A_{0} \cot \theta}$

The strength of the section, under combined shear and torsion, predicted by the AASHTO provisions can be expressed by equation [10b]:

$\frac{A_{t} f_{y}}{s}=\frac{V_{n}-V_{c}}{2 d_{v} \cot \theta}+\frac{T_{n}}{2 A_{0} \cot \theta}$ 
Similarly, considering ABNT NBR 6118: 2014 provisions, equation [11] is obtained:

$$
\frac{A_{t} f_{y w d}}{s}=\frac{V_{s d}-V_{c}}{2 \cdot 0.9 d \cot \theta}+\frac{T_{s d}}{2 A_{e} \cot \theta}
$$

Another important consideration of the ABNT NBR Standards is the verification of the strength capacity of the compression strut. In this case, independently of the strut angle and the calculation model considered for the analysis, it is necessary that the structure attends the condition expressed in equation [12].

$\frac{V_{s d}}{V_{R d 2}}+\frac{T_{s d}}{T_{R d 2}} \leq 1$

To avoid crushing of the concrete before yielding of the reinforcement and to limit crack widths at service loads, the ACI Code requires that, for solid sections, the nominal shear stress be limited such that equation [13] is valid.

$\sqrt{\left(\frac{V_{n}}{b_{w} d}\right)^{2}+\left(\frac{T_{n} p_{h}}{1.7 A_{o h}^{2}}\right)^{2}} \leq 0.83 \sqrt{f_{c}^{\prime}} \quad\left(f_{c}^{\prime}\right.$ in MPa)

For hollow sections, the nominal shear stress is limited as:

$\frac{V_{n}}{b_{w} d}+\frac{T_{n} p_{h}}{1.7 A_{o h}^{2}} \leq 0.83 \sqrt{f_{c}^{\prime}} \quad\left(f_{c}^{\prime}{ }^{\prime}\right.$ in $\left.\mathrm{MPa}\right)$

To avoid concrete crushing failures, the AASHTO provisions for shear stress is limited by equation [15]:

$\sqrt{\left(\frac{V_{n}}{b_{v} d_{v}}\right)^{2}+\left(\frac{T_{n} p_{h}}{A_{o h}^{2}}\right)^{2}} \leq 0.25 f_{c}^{\prime} \quad$ (f $f_{c}^{\prime}$ in $\left.\mathrm{MPa}\right)$

\section{Analytical comparison between the ACl, ABNT NBR 6118, and AASHTO}

The most relevant variable in this analysis is the angle $\theta$ between the compression strut and the longitudinal reinforcement. How the variation of the angle $\theta$ influences the provisions of the concrete contribution to resist shear in the three Standard codes is shown in Example 1. This example is based on the experimental evaluation made by Rahal \& Collins [3] so the analytical results in this study could also be compared to some experimental observation.

How the failure of the concrete strut is verified by the $\mathrm{ACl}$ and the ABNT NBR codes are shown in Example 2. This is a very simple example because the purpose here is to compare in an easy way how both codes may consider the variation (or not) of the angle $\theta$.

\subsection{Example 1}

The same reinforced concrete beam, part of a grid of beams, which was used in Rahal \& Collins [3] for their specimens (see Fig. 5) is considered. The clear span of this beam is $166 \mathrm{~cm}$ (200 cm axis to axis). The section of the beam is $340 \times 640 \mathrm{~mm}$. It is subjected to a constant shear force $P$, a constant torsional moment and a linearly varying bending moment (from $-\mathrm{P}$ to $+\mathrm{P}$ ) with a value of zero at the centerline. At one end of the beam, the longitudinal reinforcement consists of five No. 25 bars in one layer near the top face and 10 No. 25 bars in two layers near the bottom face. Each of these bars has an area of $500 \mathrm{~mm}^{2}$ and a yield stress of $480 \mathrm{MPa}$. At the other end of the beam, the cross-sectional details are similar except the second layer of five bars is placed near the top face. The second layer of bars, near the bottom at the east end and near the top at the west end, is terminated $100 \mathrm{~mm}$ beyond the "zero moment" location. The continuous outer layers of longitudinal bars are placed with their centers $70 \mathrm{~mm}$ from the outer faces, while the inner layers are placed $130 \mathrm{~mm}$ from the outer faces.

The transverse reinforcement is uniform throughout the beam's length and consists of No. 10 closed stirrups, with centerline dimensions of $245 \times 545 \mathrm{~mm}$, spaced at $125 \mathrm{~mm}$ centers. The No. 10 bars has an area of $100 \mathrm{~mm}^{2}$ and a yield strength of $466 \mathrm{MPa}$. The concrete compressive strength that is considered as $f_{c}$ 'and $f_{c k}$ is $46 \mathrm{MPa}$. For the cross section studied, the shear strength $\left(\mathrm{V}_{\text {sd }}\right.$ considering ABNT NBR 6118: 2014 or $\mathrm{V}_{\mathrm{n}}$ considering $\mathrm{ACl}$ or AASHTO) when torsion is zero, can be calculated from equations [8] and [9] respectively. Model II is being considered to obtain $\mathrm{V}_{\mathrm{sd}}$ using ABNT NBR 6118: 2014 because it can be more accurate when varying the angle of the strut $\theta$.

\section{ABNT NBR 6118: 2014:}

$V_{s d}=0.6 f_{c t d} b_{w} d+\left(\frac{A_{s w}}{s}\right) 0.9 d f_{y w d}=$

$=0.6 \cdot 1.93 \cdot 0.34 \cdot 0.57 \cdot 10^{3}+\left(\frac{2 \cdot 100}{125}\right) 0.90 \cdot 0.57 \cdot 435^{*} \cdot \cot \theta=$

$=224+357 \cot \theta \mathrm{kN}$

*It should be pointed out that ABNT NBR 6118 does not allow the value for the yield strength higher than $435 \mathrm{MPa}$. So, in this case, $466 \mathrm{MPa}$ cannot be used for the ABNT NBR 6118 expressions, and the value of $435 \mathrm{MPa}$ was used.

ACl:

$V_{n}=0.166 \sqrt{46} \cdot 0.34 \cdot 0.57 \cdot 10^{3}+\frac{2 \cdot 100 \cdot 466}{125} 0.57=$

$=218+425=643 \mathrm{kN}$

\section{AASHTO:}

$V_{n}=0.083 \cdot 1.50 \cdot \sqrt{46} \cdot 0.34 \cdot 0.54 \cdot 10^{3}+\frac{2 \cdot 100 \cdot 466}{125} \cdot 0.54 \cdot \cot 35.8$

$=155+558=713 \mathrm{kN}$

( $\theta$ and $\beta$ were taken from Table 1 considering $\varepsilon_{x}$ equal or less than $1.00 \times 10^{-3}$ and $v / f_{c}^{\prime}$ ' equal or less than 0.25 ).

Verifying the concrete strut when torsion is zero:

According to ABNT NBR 6118:2014:

$\theta=30^{\circ}$

$\frac{V_{s d}}{V_{R d 2}}+\frac{T_{s d}}{T_{R d 2}} \leq 1 \quad \rightarrow \frac{842}{0.27\left(1-\frac{46}{250}\right) \frac{46}{1.4} 0.34 \cdot 0.57 \cdot 10^{3}}+0 \leq 1$ ok! $\theta=45^{\circ}$

$\frac{V_{s d}}{V_{R d 2}}+\frac{T_{s d}}{T_{R d 2}} \leq 1 \quad \rightarrow \frac{581}{0.27\left(1-\frac{46}{250}\right) \frac{46}{1.4} 0.34 \cdot 0.57 \cdot 10^{3}}+0 \leq 1$ ok!

According to $\mathrm{ACl}$ :

$\sqrt{\left(\frac{V_{n}}{b_{w} d}\right)^{2}+\left(\frac{T_{n} p_{h}}{1.7 A_{o h}^{2}}\right)^{2}} \leq 0.83 \sqrt{f_{c}^{\prime}} \rightarrow \sqrt{\left(\frac{643}{0.34 \cdot 0.57 \cdot 10^{3}}\right)^{2}+0}=3.32 \leq 5.63$

ok!

According to AASHTO $\left(\theta=36^{\circ}\right)$ :

$\sqrt{\left(\frac{V_{n}}{b_{v} d_{v}}\right)^{2}+\left(\frac{T_{n} p_{h}}{A_{o h}^{2}}\right)^{2}} \leq 0.25 f_{c}^{\prime} \rightarrow \sqrt{\left(\frac{713}{0.34 \cdot 0.54 \cdot 10^{3}}\right)^{2}+0}=3.88 \leq 11.5$

ok! 


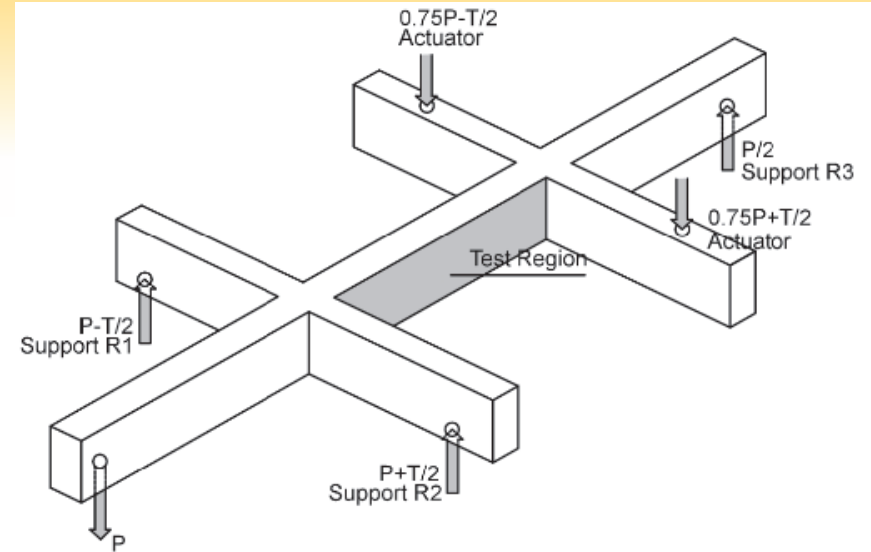

(a) Perspective view of typical speciment

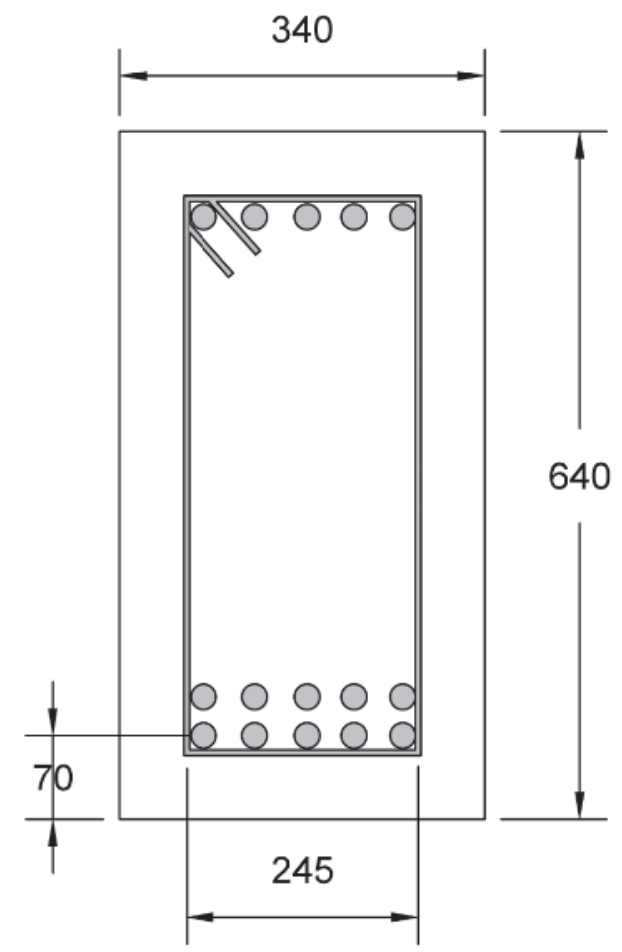

(c)Cross Section
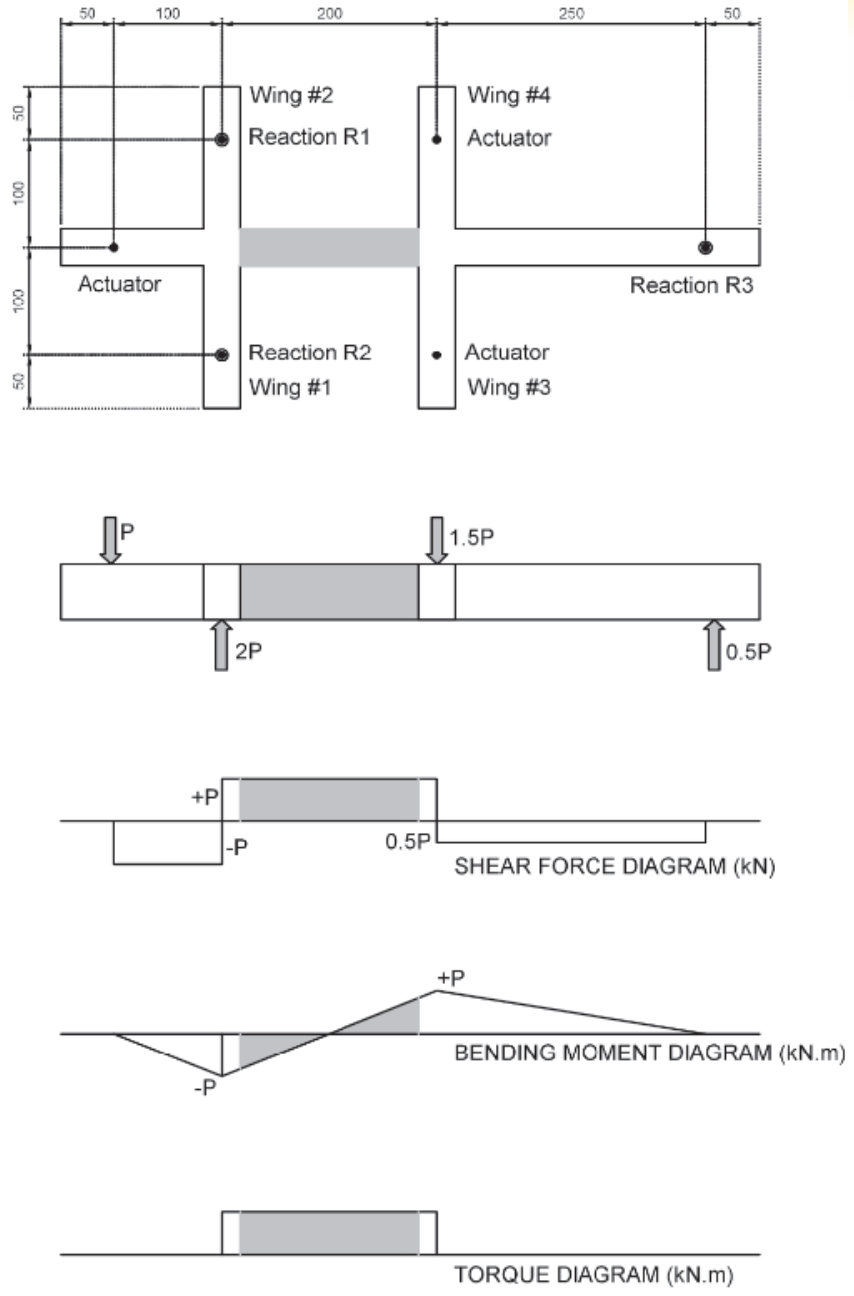

(b) Plan and side view of the specimen showing forces in the test region

\section{Figure 5}

Test details used by Rahal \& Collins [3] and also in this example

The torsional strength ( $T_{\text {sd }}$ considering ABNT NBR 6118 or $T_{n}$ considering $\mathbf{A C l}$ or AASHTO) when shear is zero, can be calculated using expressions [4] and [6], respectively.

\section{ABNT NBR 6118: 2014:}

$T_{s d}=\left(\frac{100}{125}\right) 435 \cdot 2 \cdot 0.245 \cdot 0.545 \cdot \cot \theta=93 \cot \theta \mathrm{kN} . \mathrm{m}$

\section{ACI/AASHTO:}

$T_{n}=2 \cdot 0.85 \cdot 0.245 \cdot 0.545 \cdot\left(\frac{100 \cdot 466}{125}\right) \cot \theta=84.6 \cot \theta \quad \mathrm{kN} . \mathrm{m}$

- Verifying the concrete strut for pure torsion:

According to ABNT NBR 6118: 2014:

$\theta=30^{\circ}$

$\frac{V_{s d}}{V_{R d 2}}+\frac{T_{s d}}{T_{R d 2}} \leq 1 \rightarrow$

$0+\frac{161.08}{0.5\left(1-\frac{46}{250}\right) \frac{46}{1.4} 0.245 \cdot 0.545 \cdot 0.085 \cdot \sin 2 \theta \cdot 10^{3}} \leq 1$

$=1.22$ not $o k$ ! $\theta=45^{\circ}$

$\frac{V_{s d}}{V_{R d 2}}+\frac{T_{s d}}{T_{R d 2}} \leq 1$

$0+\frac{93}{0.5\left(1-\frac{46}{250}\right) \frac{46}{1.4} 0.245 \cdot 0.545 \cdot 0.085 \cdot \sin 90 \cdot 10^{3}} \leq 1$

$=0.4 \quad \mathrm{ok}$ !

According to $\mathrm{ACl}$ :

$\theta=30^{\circ}$

$\sqrt{\left(\frac{V_{n}}{b_{w} d}\right)^{2}+\left(\frac{T_{n} p_{h}}{1.7 A_{o h}^{2}}\right)^{2}} \leq 0.83 \sqrt{f_{c}^{\prime}} \rightarrow$
$\sqrt{0+\left(\frac{146.5 \cdot 2 \cdot(0.245+0.545)}{1.7 \cdot 0.245^{2} \cdot 0.545^{2} \cdot 10^{3}}\right)^{2}} \leq 5.63$

$=7.64$ not ok! 
$\theta=45^{\circ}$

$$
\begin{aligned}
& \sqrt{\left(\frac{V_{n}}{b_{w} d}\right)^{2}+\left(\frac{T_{n} p_{h}}{1.7 A_{o h}^{2}}\right)^{2}} \leq 0.83 \sqrt{f_{c}^{\prime}} \\
& \sqrt{0+\left(\frac{84.6 \cdot 2 \cdot(0.245+0.545)}{1.7 \cdot 0.245^{2} \cdot 0.545^{2} \cdot 10^{3}}\right)^{2}} \leq 5.63
\end{aligned}
$$$$
=4.41 \mathrm{ok} \text { ! }
$$

According to $\mathrm{ACl}$ and $\mathrm{ABNT}$ NBR provisions, this section would fail by crushing of the concrete in case of pure torsion and when $\theta=30^{\circ}$. If $\theta=45^{\circ}$ is considered, this section is practicable.

According to AASHTO $\left(\theta=36^{\circ}\right)$ :

$$
\begin{aligned}
& \sqrt{\left(\frac{V_{n}}{b_{v} d_{v}}\right)^{2}+\left(\frac{T_{n} p_{h}}{A_{o h}^{2}}\right)^{2}} \leq 0.25 f_{c}^{\prime} \rightarrow \\
& \sqrt{0+\left(\frac{116.4 \cdot 2 \cdot(0.245+0.545)}{0.245^{2} \cdot 0.545^{2} \cdot 10^{3}}\right)^{2}}=10.4 M P a \leq 11.5
\end{aligned}
$$

ok!

The relation between shear and torsion shown in equations [10] and [11], can be used to plot a shear-torsion interaction diagram (Fig. 6), that can be used to compare the results obtained by the ABNT NBR 6118, ACI, AASHTO and the four specimen results obtained by Rahal and Collins (Table 2), for different values of $\theta$.

$$
\begin{aligned}
& \text { ABNT NBR } 6118 \text { Curve } \\
& \begin{array}{l}
100 \cdot 435 \\
125
\end{array}=\frac{V_{s d}-224}{2 \cdot 0.9 \cdot 570 \cdot \cot \theta}+\frac{T_{s d}}{2 \cdot 0.245 \cdot 0.545 \cdot \cot \theta} \\
& 348=\frac{V_{s d}-224}{1.026 \cdot \cot \theta}+\frac{T_{s d}}{0.267 \cdot \cot \theta}
\end{aligned}
$$

\section{ACl Curve}

$\frac{100 \cdot 466}{125}=\frac{V_{n}-218}{2 \cdot 570}+\frac{T_{n}}{2 \cdot 0.85 \cdot 0.245 \cdot 0.545 \cdot \cot \theta}$

$373=\frac{V_{n}-218}{1.14}+\frac{T_{n}}{0.227 \cdot \cot \theta}$

\section{AASHTO Curve [19b]}

$$
\begin{aligned}
& \frac{100 \cdot 466}{125}=\frac{V_{n}-98.2 \beta}{2 \cdot 540 \cdot \cot \theta}+\frac{T_{n}}{2 \cdot 0.85 \cdot 0.245 \cdot 0.545 \cdot \cot \theta} \\
& 373 \cdot \cot \theta=\frac{V_{n}-98.2 \beta}{1.08}+\frac{T_{n}}{0.227}
\end{aligned}
$$

\section{Table 2}

Specimen results from Rahal \& Collins [3]

\begin{tabular}{ccc}
\hline Speciman & T (kN.m) & V (kN) \\
\hline RC2-1 & 83 & 535 \\
RC2-2 & 0 & 796 \\
RC2-3 & 135 & 111 \\
RC2-4 & 55 & 715 \\
\hline
\end{tabular}

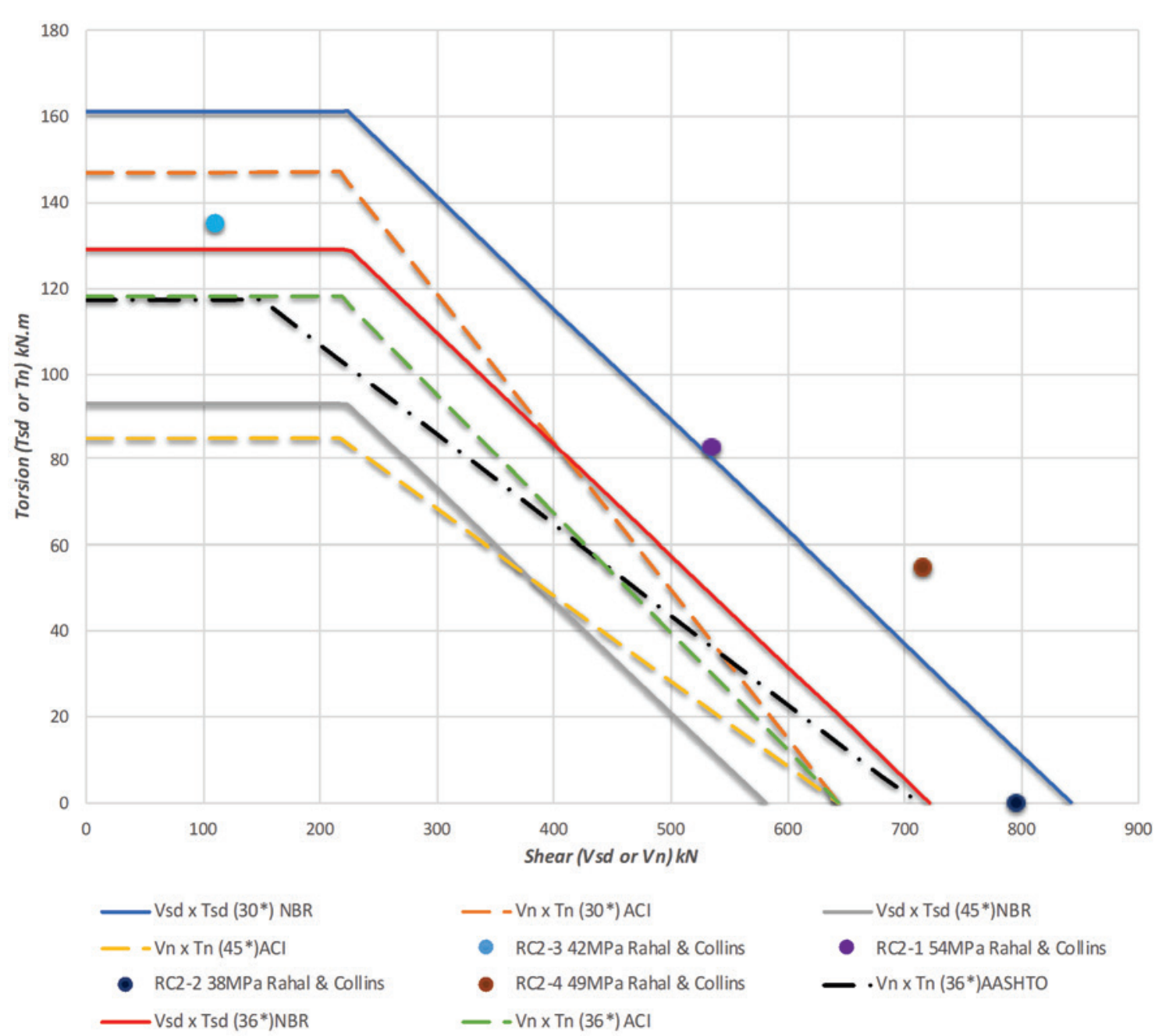

\section{Figure 6}

Shear-torsion interaction diagrams comparing ACl, AASTHO, ABNT NBR 6118 and specimens 
PLAN

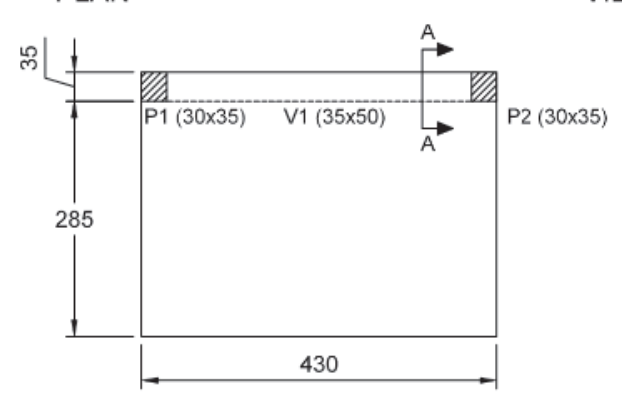

VIEW 1

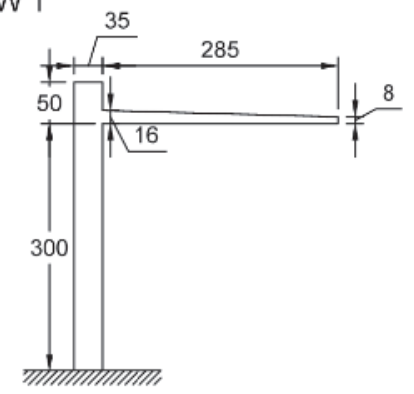

SECTION A-A

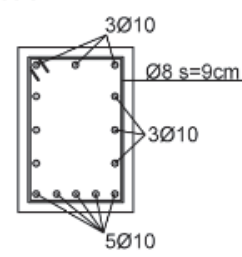

Figure 7

Beam V1 from Example 2
VIEW 2

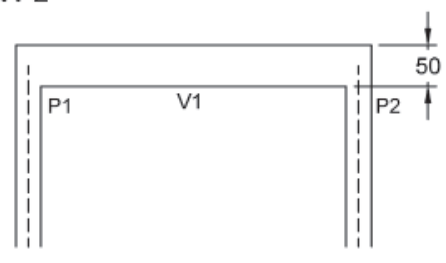

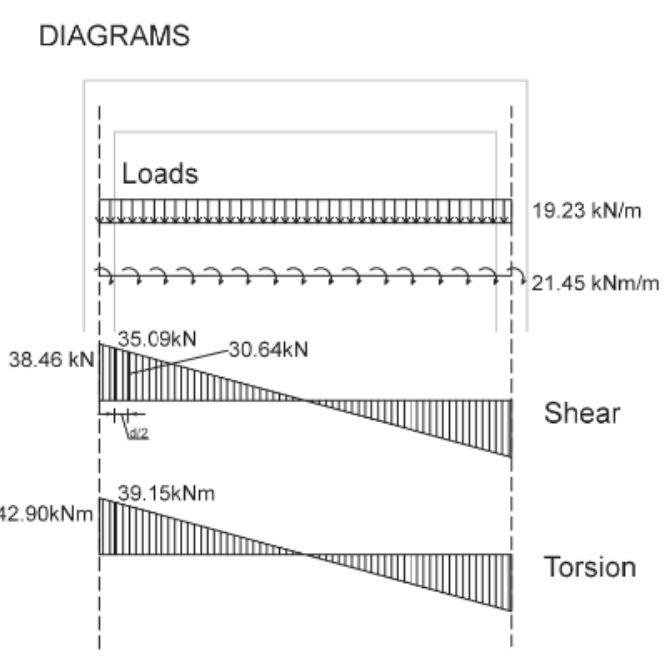

It is worth mentioning that for this nonprestressed section, no significant gain in accuracy is obtained by calculating $\varepsilon_{\mathrm{x}}$ as opposed to using the allowable value of $1.00 \times 10^{-3}$. On the other hand, the shear stress ratio $v_{u} / f_{c}$ ' changes significantly going from 0.225 for pure torsion down to 0.091 for the "zero torsion" case. This reduction in shear stress enables the value of $\beta$ to be increased from 1.64 to 2.18 (refer to Table 1).

The seven interaction diagrams shown in Fig. 6 each consist of two straight lines. A horizontal plateau defines the cases where the pure torsional capacity of the section limits the strength of the section. Hence, the applied shear is less than $V_{c}$. The second straight line defines the pure torsion capacity and $V_{c}$, with the last point being the shear capacity when the torsion is zero. Here, the combination of torsion and shear cause yielding of the closed stirrup on one side of the section as defined by equations [18] and [19].

As seen here and by Rahal \& Collins, very conservative estimates of the torsional strengths are obtained when the $\mathrm{ACl}$ provisions are applied using the recommended value of 45 degrees for $\theta$. On the other hand, if the lowest permitted value of 30 degrees is used for $\theta$, then less consistent results are obtained, with the predictions becoming less conservative as the ratio of torsion to shear increases. The AASHTO provisions give results that are conservative and consistent at the same time. Rahal \& Collins also show that near failure, the inclination of cracks on the faces where torsion and shear effects are additive are much flatter than $45^{\circ}$ and are close to the angles predicted by the AASHTO provisions.

As it can be clearly seen in Fig. 6, that for $\theta$ of $30^{\circ}$, there is a significant difference between the results obtained using the provisions of the ACl code and the ABNT NBR 6118 while for $\theta$ of $45^{\circ}$, the results obtained for both codes are closer. This is mostly due to the shear force because in the ACl code, the shear does not depend on the variation of $\theta$ (and $\theta$ is considered $45^{\circ}$ ). While in the NBR Standards, both shear and torsion are function of $\theta$. The same thing happens to AASHTO provisions which also considers that shear and torsion are function of $\theta$. That explains why the $\mathrm{ACI}$ code results for $\theta$ different then 45 degrees departs from the results obtained using the Brazilian Standard provisions.

\subsection{Example 2}

The purpose of this example is to compare in a simple way how the provisions of $\mathrm{NBR}$ and $\mathrm{ACl}$ codes verifies the failure of concrete strut. The beam V1 $(35 \mathrm{~cm} \times 50 \mathrm{~cm})$ shown in Fig. 7 is subjected to torsion, besides shear and bending moment. The concrete compressive strength that is considered as $f_{c}$ ' and $f_{c k}$ is $25 \mathrm{MPa}$. Clear cover considered for this example is $3 \mathrm{~cm}$. The compression strut for $\theta=45^{\circ}$ and $\theta=30^{\circ}$ in both provisions ( $\mathrm{ACl}$ and NRB) are checked and the results compared.

- Verifying the concrete strut:

According to ABNT NBR 6118:2014:

$\mathrm{V}_{\text {sd }}=1.4 \times 35.09=49.13 \mathrm{kN} \quad \mathrm{T}_{\mathrm{sd}}=1.4 \times 39.15=54.81 \mathrm{kN} . \mathrm{m}$

Considering $\theta$ of $45^{\circ}$ and equation [1a]:

$V_{R d 2}=0.27\left(1-\frac{f_{c k}}{250}\right) f_{c d} b_{w} d=$

$0.27\left(1-\frac{25}{250}\right) \frac{25000}{1.4} \cdot 0.35 \cdot 0.47=713.81 \mathrm{kN}$

Considering $h_{e}=8 \mathrm{~cm}, A_{e}=(35-8) \times(50-8)=1134 \mathrm{~cm}^{2}$, so:

$T_{R d 2}=0.50\left(1-\frac{f_{c k}}{250}\right) f_{c d} A_{e} h_{e} \sin (2 \theta)=0.50\left(1-\frac{25}{250}\right) \frac{25000}{1.4}$.

$0.1134 \cdot 0.08 \cdot \sin (90)=72.9 \mathrm{kN} . \mathrm{m}$

So, according to equation [12]:

$\frac{V_{s d}}{V_{R d 2}}+\frac{T_{s d}}{T_{R d 2}} \leq 1 \quad \rightarrow \quad \frac{49.13}{713.81}+\frac{54.81}{72.9}=0.82 \leq 1 \quad O k !$

It should be pointed out that the gap that there is between 0.82 and 1 permits the inclination of the strut to be smaller. 
Considering $\theta$ of $30^{\circ}$ and equation [2a]:

$V_{R d 2}=0.54\left(1-\frac{f_{c k}}{250}\right) f_{c d} b_{w} d(\sin \theta)^{2} \cot \theta=0.54\left(1-\frac{25}{250}\right) \frac{25000}{1.4}$.

$0.35 \cdot 0.47 \cdot 0.25 \cdot 1.732=618.16 \mathrm{kN}$

Considering $\mathrm{h}_{\mathrm{e}}=8 \mathrm{~cm}, \mathrm{~A}_{\mathrm{e}}=1134 \mathrm{~cm}^{2}$, then:

$T_{R d 2}=0.50\left(1-\frac{f_{c k}}{250}\right) f_{c d} A_{e} h_{e} \sin (2 \theta)=0.50\left(1-\frac{25}{250}\right) \frac{25000}{1.4}$.

$0.1134 \cdot 0.08 \cdot \sin (60)=63.13 \mathrm{kN} . \mathrm{m}$

So, according to equation [12]:

$\frac{V_{s d}}{V_{R d 2}}+\frac{T_{s d}}{T_{R d 2}} \leq 1 \quad \rightarrow \quad \frac{49.13}{618.16}+\frac{54.81}{63.13}=0.95 \leq 1$ Ok!

According to ABNT NBR provisions, the strut inclination for this example can be considered any value between $45^{\circ}$ and $30^{\circ}$.

According to $\mathrm{ACl}$ :

$V_{n}=V_{c}+V_{s}=0.166 \sqrt{25} \cdot 0.35 \cdot 0.47 \cdot 10^{3}+\frac{2 \cdot 0.5 \cdot 10^{2} \cdot 500}{90} \cdot 0.47=$

$136.54+261.11$

$=397.65 \mathrm{kN}$

$T_{n}=2 \cdot 0.85 \cdot 0.29 \cdot 0.44 \cdot\left(\frac{50.500}{90}\right) \cot (30)=104.36 \mathrm{kN} . \mathrm{m}$

So, according to equation [13]:

$\sqrt{\left(\frac{397.65}{0.35 \cdot 0.47} \cdot 10^{-3}\right)^{2}+\left(\frac{104.36 \cdot 2(0.29+0.44)}{1.7 \cdot(0.29 \cdot 0.44)^{2}} \cdot 10^{-3}\right)^{2}} \leq 0.83 \sqrt{25}$

$\sqrt{5.84+30.3}=6>4.15$ Not Ok!

According to $\mathrm{ACl}$ provisions, the strut inclination of $30^{\circ}$ for this example does not satisfy equation [13], so it cannot be considered.

This concludes that for this example, if the ABNT NBR Standards is used for this cross section, its provisions are satisfied for either angle $\theta$ considered, while if $\mathbf{A C l}$ code is used, only considering the strut with an angle of $\theta=45^{\circ}$ its provisions are satisfied.

\section{Conclusion}

The recent changes in the ABNT NBR 6118: 2014 Standards which permits that the engineer decides which angle he will consider for the inclination of the compression diagonals while designing a concrete element enables a more economic and less conservative structure when compared to the provisions of the ACI Code. The analytical study in Example 1 shows that when the recommended angle of $45^{\circ}$ is considered for $\theta$, some very conservative results are obtained for the ACl Code and for the ABNT NBR Standards for shear-torsion interaction, as shown in Fig. 6. If the lower limit of $30^{\circ}$ is used, the results obtained using both codes departs and less consistent results are obtained. When all the curves are compared to the AASHTO provisions and to the four test specimens from Rahal \& Collins [3], it concludes that using the recommended AASHTO value of $36^{\circ}$, some consistent and more accurate results are obtained. It also should be pointed out that when using $30^{\circ}$, the section in Example 1 does not satisfy the concrete crushing provisions in neither $\mathrm{ACI}$ or ABNT NBR codes.

To have a better understanding of the considerations made by the ACI Code and the ABNT NBR 6118 Standards on the verification of the compression strut failure, the simple cantilever beam from Example 2 shows that, when the same concrete cross section is studied using the ABNT NBR Standard provisions and the ACI code provisions, if designed considering the angle of the concrete strut $45^{\circ}$ they both attend the provisions. While if the designing angle used for $\theta$ is $30^{\circ}$, only the ABNT NBR Standard provisions are satisfied. This concludes that the $\mathrm{ACl}$ Codes is more conservative than the ABNT NBR 6118: 2014.

\section{Acknowledgements}

The authors express their gratitude to CAPES for the PhD scholarship of the first author and the Department of Structural Engineering of the Polytechnic School, University of São Paulo.

\section{References}

[1] Rahal K. N., Collins M. P., Analysis of Sections Subjected to Combined Shear and Torsion-A Theoretical Model, ACI Structural Journal/July-August 1995

[2] Kamara, M.E., Rabbat, B.G., Torsion Design of Structural Concrete Based on ACI 318-05, Special Advertising Section, Portland Cement Association

[3] Rahal K. N., Collins M. P., Experimental Evaluation of ACl and AASHTO-LRFD Design Provisions for Combined Shear and Torsion, ACI Structural Journal / May-June 2003

[4] Barros, R., Giongo, J.S., Shear Force and Torsion in Reinforced Concrete Beam Elements: Theoretical Analysis Based on Brazilian Standard Code ABNT NBR 6118:2007, Ibracon Structures and Materials Journal, October 2012.

[5] Collins, M. P., and Mitchell, D., Prestressed Concrete Structures, Prentice Hall, Englewood Cliffs, N.J., 1991, 766 pp.

[6] ACl Committee 318, "Building Code Requirements for Reinforced Concrete (ACl 318-71)," American Concrete Institute, Farmington Hills, Mich., 1971, 78 pp.

[7] $\mathrm{ACl}$ Committee 318, "Building Code Requirements for Structural Concrete (ACl 318-95) and Commentary (318R-95)," American Concrete Institute, Farmington Hills, Mich., 1995, 369 pp.

[8] $\mathrm{ACl}$ Committee 318, "Building Code Requirements for Structural Concrete (ACl 318-02) and Commentary (318R-14)," American Concrete Institute, Farmington Hills, Mich., 2014, 520 pp.

[9] Vecchio, F. J., and Collins, M. P., Modified Compression Field Theory for Concrete Elements Subjected to Shear, ACI Structural Journal, V. 83, No. 2, Mar.-Apr. 1986, pp. 219-231.

[10] Collins, M. P., and Mitchell, D., Shear and Torsion Design of Prestressed and Non-Prestressed Concrete Beams, Journal of the Prestressed Concrete Institute, V. 25, No. 5, Sept.-Oct. 1980, pp. 32-100.

[11] BRAZILIAN ASSOCIATION OF TECHNICAL STANDARDS NBR 61182014 - Design of Concrete Structures - Procedure. Rio de Janeiro, ABNT. 2014

[12] Mahmood, M.N., ACl Code Provisions for Torsion Design of Reinforced Concrete Beams, A Need for Revision, Journal of Applied Sciences, 7: 1293-1298, 2007. 
[13] Amulu, C.P., Ezeagu, C.A., Experimental and Analytical Comparison of Torsion, Bending Moment and Shear Forces in Reinforced Concrete Beams Using BS 8110, EURO CODE 2 AND ACI 318 Provisions, Nigerian Journal of Technology, Vol 36, No.3, July 2017, pp 705-711.

[14] Silva Filho, J.J.H., Carbon Fiber Reinforced Polymer Torsion Strengthening of Reinforced Concrete Beams, Rio de Janeiro, 2007. 280pp. PhD Thesis, PUC-RJ.

[15] AASHTO-LRFD Bridge Design Specifications, SI Units, Washington, D.C., 2012, 1661 pp.

[16] Hsu, T.T.C., Mo, Y.L., Unified Theory of Concrete Structures, Wiley, University of Huston, USA, 2010, 500pp.

[17] Pinheiro, L.M., Lima, J.S., Guarda M.C.C., Fundamentos do Concreto e Projetos de Edifício - Capítulo 18 "Torção", USP - EESC Departamento de Engenharia de Estruturas, 2007. 